\title{
Transformation and Healing Through Dance Therapy: The Challenge and Imperative of Holding the Vision
}

\author{
Marcia Leventhal
}

Published online: 4 October 2008

(C) American Dance Therapy Association 2008

Erratum to: Am J Dance Ther (2008) 30:4-23

DOI 10.1007/s10465-008-9049-8

On page 1 of this article (page 4 in Vol. 30, no. 1), in the first heading, the name of the noted dance movement therapist who introduced the 2007 Marian Chace Lecture is incorrectly spelled.

The heading should read:

Introduction to the 2007 Marian Chace Lecture by Iris Rifkin-Gainer

Our sincere apologies.

The Editors.

The online version of the original article can be found under doi:10.1007/s10465-008-9049-8. 